\title{
MINIMIZATION OF WELD DEFECTS IN MIG AND TIG WELDING
}

\author{
R. Sathesh Kumar, S. Sriram Nath, N. Sunil Kumar and K. Karthik \\ Department of Mechanical Engineering, R.M.K. College of Engineering \& Technology \\ karthick.kuppan@gmail.com
}

\begin{abstract}
Our project work done for minimizing the welding defects that occur during MIG welding at brake unit in Brakes India Ltd. Welding is the process of joining two similar or dissimilar metals permanently, where MIG welding uses inert gas for shielding and consumable metal for joining two metals. In Brake unit, the welding is performed for joining the web with the rim to form brake shoe. This welding should be very strong so as to resist the distortion due to shear force under dynamic condition. To eradicate frequent occurrences of defects such as blow hole, pin blow hole and start weld. Some of the TQM tools such as cause and effect diagram, Pareto chart, $4 \mathrm{M}$ Methodology and why-why analysis are used to identify the root cause. Hence remedial action taken such as liner cleaning, nozzle cleaning, stopper at the machine bed and tensionner at the feeding unit, helps in reducing the rework rate from 5\% to $3 \%$.
\end{abstract}

Key words: MIG welding, weld defects, TIG welding, TQM tools, cause and effect diagram, Pareto chart, 4 M Methodology and why-why analysis

\section{Introduction}

Welding is a process of joining two metal pieces by the application of heat. Welding is the least expensive process and widely used now a days in fabrication [1-4]. Welding joints different metals with the help of a number of processes in which heat is supplied either electrically or by mean of a gas torch. Different welding processes are used in the manufacturing of Auto mobiles bodies, structural work, tanks, and general machine repair work. In the industries, welding is used in refineries and pipe line fabrication. It may be called a secondary manufacturing process [5-10]. TIG and MIG welding are the most common processes for welding non-ferrous alloys [11-13].

The typical defects caused by melting and solidification such as pores, pinholes, shrinkage cracks, segregation, grain coarsening and cast structure are therefore avoided and the risk of gas pickup is low due to the short welding cycles [14-15]. As far as friction stir welding is concerned, Past experiences reveals difficulties faced during joining of $\mathrm{Al}$ to $\mathrm{Cu}$. Linear motion of the tool profile leads to the increase in feed rate value, which causes tunnel defects and voids due to the improper stirring time [16-18].

\section{MIG Welding Parameters onFusion}

This defect causes a minute hole in the fused portion, when the hole is single it is called pin blow hole if thereare numerous hole then it is called blow holes and is shown in Fig. 1.

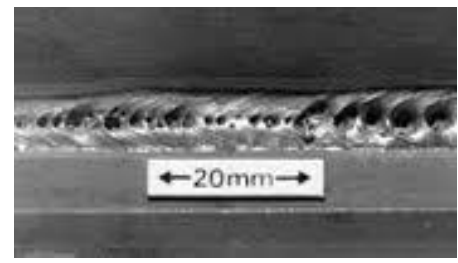

Figure 1. Blow hole defect

The starting portion of the weld region is not welded in this defect thus the starting portion remain un-welded. This is shown in Fig. 2.

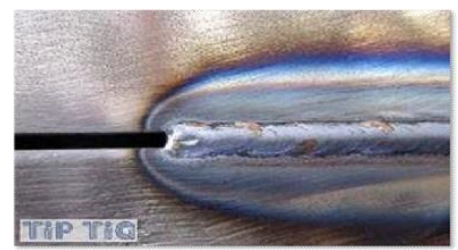

Figure 2. Start weld defect

A weld in which the continuity is broken by recurring unwelded spaces is an intermittent weld as shown in Fig. 3.

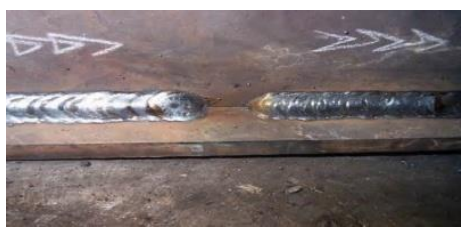

Figure 3. Intermittent weld 
ISSN NO 2582-0958

When the weld stops in between and leaves the rest of the portion un-welded then it is termed as In-complete weldas shown in Fig.4.

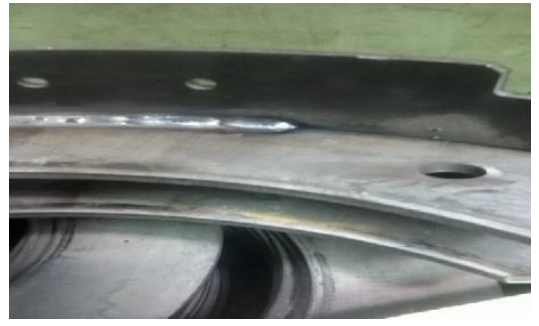

Figure 4. Incomplete weld defect

\section{Factors Responsible forDefects}

The defects are studied and analyzed to get the various possible reasons that cause the defects. The reasons are segregated in their respective groups as shown below.

\section{i. Factors responsible for Pin blow hole and blow holes are}

1) Variation in gascomposition.

2) Irregular supply ofgas.

3) Inclusion of foreignbodies.

4) Presence of oil in the rim orweb.

5) Leakage of lubricating oil on to the weldarea.

6) Moisture content in the gas that is beingsupplied.

\section{ii. Factors responsible for Startweld}

1) Delay infusion.

2) Insufficient startingvoltage.

3) Providing excessive Dwelltime.

\section{iii. Factors responsible for Intermittent Weld}

1) Irregular wirefeeding.

2) Fluctuation involtage.

3) Error intransformer.

4) Dust inliner.

5) Dust in contacttip.

\section{iv. Factors responsible for Incompleteweld}

1) Completion of weld wire in midway of welding operation.

2) Strucken weldwire

\section{Validation ofcauses}

Table 1. Validation of Causes

\begin{tabular}{|l|l|c|}
\hline \multicolumn{1}{|c|}{ CAUSES } & SOURCE & SIGNIFICANCE \\
\hline $\begin{array}{l}\text { Completion of } \\
\text { weld wire }\end{array}$ & $\begin{array}{l}\text { Welding wire } \\
\text { barrel }\end{array}$ & Significant \\
\hline $\begin{array}{l}\text { Leakage of oil } \\
\text { on welding } \\
\text { region }\end{array}$ & Lubrication oil & Significant \\
\hline $\begin{array}{l}\text { Nozzle dust } \\
\text { Variation of } \\
\text { voltage }\end{array}$ & $\begin{array}{l}\text { Welding fumes } \\
\text { transformer }\end{array}$ & Significant \\
\hline Oil on the job & supplier & Significant \\
\hline $\begin{array}{l}\text { Dust in the } \\
\text { liner }\end{array}$ & $\begin{array}{l}\text { Copper coat on } \\
\text { weld wire }\end{array}$ & Significant \\
\hline
\end{tabular}

\section{Countermeasures}

Ring sensor is being installed for governing the availability of welding wire. This ring senses the presence of welding wire in it and alarms when the wire doesn't pass through its passage. By providing this sensor we can lessen the incomplete weld defect jobs. The name of this sensor is Ring Style Inductive ProximitySensor.

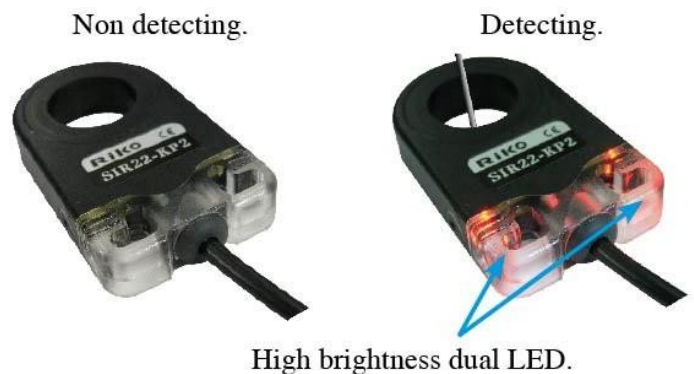

Figure 5. Operating conditions of sensors

This will also lead to reduce the defect rate. The wire needed for welding one cycle is about 5 meters so the sensor should be placed before 4 meters so that there won't be any incomplete welddefect. 
The next counter measure is for cleaning the liner that allows the weld wire to pass through it so that the weld wire passes through the liner smoothly and continuously. For accomplishing this we provide a T-Joint before the feeder unit where two opposite passage are for the provision for weld wire inlet and outlet. The third passage is for the inlet of pressurized air the third passage is supplemented with paint thinner using a container, this container is provided with small hole at the top of the container so as to maintain the pressure on the thinner. This setup is shown in the fig. 6 shown below.

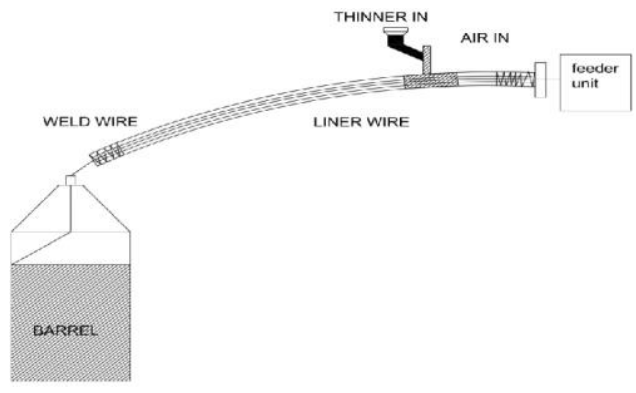

Figure 6. Recommended setup

For cleaning the torch liner after the feeder unitwe provide a solenoid valve, this solenoid valve is used to provide an alternate supply of air and gas that is when air is supplied gas flow is shut and vice-versa. Here the paint thinner is not used because it will cause voltage fluctuation or it may leak on to the weld area thus creating a pin blowhole. This setup is shown in the Fig.7.

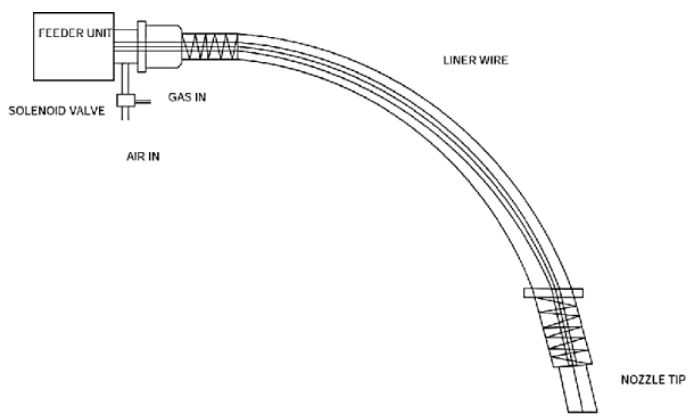

Figure 7. Recommended setup

\section{References}

[1] C.D. Lundin "Discontinuities in welds - Cause and effect relation", Journal of Materials for Energy systems, 1983, Volume5.

[2] Dr-Ing. Habil. Dieter Radaj "Reduction of welding residual stresses \& distortion", Heat effects of Welding, 1993.

[3] H.J. Park, D.C. Kim, M.J. Kang and S. Rhee "Optimisation of the Wire Feed Rate during Pulse MIG Welding of Al Sheets", Journal of achievements in Material \& Manufacturing Engineering, 2008, Volume27.

[4] K. Kishore, P.V. Gopal Krishna, K. Veladri and Syed Qasim Ali," Analysis of defects in gas shielded arc welding of AISI1040 steel using Taguchi method", ARPN Journal of Engineering and Applied Sciences, 2010, Volume5.

[5] Dr. John J. Lowke, Dr. Anthony B. Murphy and Prof Manabu Tanaka," Metal Vapour in MIG Arcs Can Cause (1) Minima in Central Arc Temperatures and (2) Increased Arc Voltages", Welding in the World, 2013, Volume54.

[6] Dr.-Ing. Michael schnick, Dipl.-Ing. Michael Dreher, Dr.-Ing. JörgZschetzsche, Prof. Dr.-Ing. habil. Uwe Füssel and Dr. rer. nat. Andreas Spille-Kohoff,"Visualisation and Optimisationof Shielding gas flows in Arc welding", welding in the world, 2013, Volume56.

[7] Mr. Harshal K. Chavan, Mr. Gunwant D.Shelake and Dr. M. S. Kadam," Input and Speed of Welding on Distortion in MIG Welding", International Journal of Industrial Engineering Research and Development, 2012, Volume3.

[8] A. Haelsig, M. Kusch and P. Mayer, "New Findings on the Efficiency of Gas Shielded Arc Welding", Welding in the World, 2012, Volume 56.

[9] Faheem Yousaf and Dr. Shahid IkramullahButt," Reduction in Repair rate of Welding Processes by Determination \& Controlling of Critical KPIVs", International Journal of Production Management and Engineering, 2013, Volume2.

[10] M. Ebert-Spiegel, S.-F. Goecke and M. Rethmeier," Efficient gap filling in MAG welding using optical sensors", Welding in the World, 2014, Volume58. 
[11] M. Balasubramanian, V. Jayabalan, and V. Balasubramanian, "Response surface approach to optimize the pulsed current gas tungsten arc welding parameters of Ti-6Al-4V titanium alloy," Metals and Materials International, vol. 13, no. 4, pp. 335-344, 2007, doi: 10.1007/BF03027891.

[12] M.Balasubramanian, V. Jayabalan, and V. Balasubramanian, "Optimizing the pulsed current GTAW parameters to attain maximum impact toughness," Materials and Manufacturing Processes, vol. 23, no. 1, pp. 69-73, 2008, doi:10.1080/10426910701524584.

[13] M. Balasubramanian, V. Jayabalan, and V. Balasubramanian, "Process parameter optimization of the pulsed current argon tungsten arc welding of titanium alloy," Journal of Materials Science and Technology, vol. 24, no. 3, pp. 423-426, 2008.

[14] M. Balasubramanian, V. Jayabalan, and V. Balasubramanian, "Modeling corrosion behavior of gas tungsten arc welded titanium alloy," Transactions of Nonferrous Metals Society of China (English Edition), vol. 17, no. 4, pp. 676-680, 2007, doi: 10.1016/S10036326(07)60155-1.

[15] M. Balasubramanian, "Prediction of optimum weld pool geometry of PCTIG welded titanium alloy using statistical design," Engineering Science and Technology, an International Journal, vol. 19, no. 1, pp. 1521, 2016, doi: 10.1016/j.jestch.2015.06.001.

[16] M. Balasubramanian and D. Jayabalakrishnan, "Influence of Pin Offset and Weave Pattern on the Performance of Al-Cu Joints Reinforced with Graphene Particles," International Journal of Automotive and Mechanical Engineering, vol. 17, no. 3, pp. 8186-8196, 2020, doi: 10.15282/ijame.17.3.2020.12.0616.

[17] D.Jayabalakrishnan and M. Balasubramanian, "Friction stir weave welding (FSWW) of AA6061 aluminium alloy with a novel toolpath pattern,"Australian Journal of Mechanical Engineering, vol. 17, no. 2, pp. 133-144, 2019,doi:10.1080/14484846.2017.1373584.
[18] D.Jayabalakrishnan and M. Balasubramanian, "Friction stir welding of dissimilar butt joints with novel joint geometry," Acta Physica Polonica A, vol.133, no. 1, pp. 94-100, 2018, doi:10.12693/APhysPolA.133.94 